\title{
PENGARUH BUDAYA DAN KOMITMEN ORGANISASI SERTA HUBUNGANNYA ANTARA PARTISIPASI PENGANGGARAN DAN KINERJA MANAJERIAL PERUSAHAAN AMDK DI PASURUAN
}

\author{
Titik Wijayanti \\ Magister Manajemen Universitas Muhammadiyah Malang \\ E-mail: titikwijayanti98@yahoo.com
}

\begin{abstract}
ABSTRACK
This study examines the effects of 1) budgetary participation on the managerial performance and 2) organizational culture on moderating relationship between budgetary participation and managerial performance. This study also examine organizational commitment on moderating the relationship between budgetary participation and managerial performance. This study use data obtained from AMDK companies in Pasuruan through proportional stratified sampling. This studies' respondents are middle and lower managers in 20 AMDK companies in Pasuruan, East Java, Indonesia. From 120 questionnaires distribute to respondents, only 68 questionnaires were returned and were useable for analysis a response rate of 56,67 \%. The method to analyze data is a moderating regression analysis. The results show that budgetary participation has no influence on managerial performance. Organizational culture as moderating variable has no influence on relationship between budgetary participation and managerial performance. Organizational commitment as moderating variable has a negative influence and significant relationship between budgetary participation and managerial performance.
\end{abstract}

Keywords: organizational culture, organizational commitment, budgetary participation and managerial performance

\section{PENDAHULUAN}

Banyak penelitian bidang akuntansi manajemen yang meneliti masalah partisipasi penyusunan anggaran/ partisipasi penganggaran dan kinerja manajerial. Hasil penelitian tersebut berbeda anatara peneliti yang satu dengan yang lain. Penelitian Sumarno (2005) menunjukkan bahwa partisipasi anggaran berpengaruh dan berhubungan negatif yang kuat terhadap kinerja manajerial. Rinarti dan Renyowijoyo (2007) menyatakan bahwa partisipasi anggaran berpengaruh secara signifikan terhadap kinerja. Hasil penelitian LeachLopez et al. (2007) menyatakan bahwa ada asosiasi yang kuat dalam hubungan antara partisipasi anggaran dengan kinerja manajerial. Sardjito dan Muthaher (2008), Eker (2008), serta Rudhianto (2010) menyatakan bahwa partisipasi penyusunan anggaran perpengaruh positif dan signifikan terhadap kinerja manajerial.

Sehubungan dengan penelitian tersebut, berbagai peneliti menyarankan untuk menggunakan pendekatan kontinjensi karena sistem manajemen setiap perusahaan diterapkan pada situasi dan kondisi yang berbeda. Sardjito dan Muthaher (2007) menggunakan budaya dan komitmen organisasi sebagai variabel moderating. Hasil penelitiannya menunjukkan bahwa budaya organisasi berpengaruh secara signifikan dalam memoderasi hubungan antara partisipasi penyusunan anggaran dengan kinerja aparat daerah. Demikian pula dengan komitmen organisasi yang hasilnya menunjukkan bahwa terdapat pengaruh yang signifikan dalam memoderasi hubungan antara partisipasi penyusunan anggaran dengan kinerja aparat 
daerah. Rinarti dan Renyowijoyo (2007) menyatakan bahwa terdapat pengaruh budaya organisasi terhadap hubungan antara partisipasi penyusunan anggaran dan kinerja manajerial. Hasil penelitian Sumarno (2005) menunjukkan bahwa komitmen organisasi berpengaruh positif dan signifikan terhadap hubungan antara partisipasi penyusunan anggaran dengan kinerja manajerial.

Termotivasi dari hasil penelitian tersebut maka peneliti melakukan replikasi terhadap penelitian Sardjito dan Muthaher (2007). Perbedaan antara penelitian ini dengan penelitian Sardjito dan Muthaher adalah objek penelitian. Penelitian ini dilakukan pada manajer perusahaan swasta sedangkan penelitian Sardjito dan Muthaher (2007) pada aparat pemerintah kota dan kabupaten di Semarang. Penelitian ini bertujuan untuk menguji kembali apakah partisipasi penganggaran berpengaruh positif dan signifikan terhadap kinerja manajerial. Selain itu juga menguji apakah budaya dan komitmen organisasi dapat memoderasi hubungan antara partisipasi penganggaran dengan kinerja manajerial secara positif dan signifikan.

\section{TINJAUANPUSTAKA}

Teori kontinjensi menyatakan bahwa perencanaan dan penggunaan desain sistem pengendalian manajemen bergantung pada karakteristik dan kondisi organisasi di mana sistem tersebut diterapkan (Fisher, 1998 dalam Ardianto, 2008). Pendekatan teori kontinjensi pada penelitian ini digunakan untuk mengevaluasi keefektifan partisipasi penganggaran terhadap kinerja manajerial. Faktor kontinjensi yang digunakan dalam penelitian ini yaitu budaya dan komitmen organisasi. Faktor-faktor tersebut akan bertindak sebagai variabel pemoderasi dalam hubungan antara partisipasi penganggaran dengan kinerja manajerial. Variabel pemoderasi merupakan variabel independen yang akan memperkuat atau memperlemah hubungan antara variabel independen lainnya terhadap variabel dependen (Ghozali, 2005).

Kinerja manajerial merupakan seberapa jauh seorang manajer melaksanakan fungsi-fungsi manajemen. Kinerja manajerial didasarkan pada fungsi-fungsi manajemen yang meliputi perencanaan, investigasi, pengkoordinasian, evaluasi, pengawasan, pemilihan staf, negosiasi, dan perwakilan. Kinerja seorang manajer berorientasi pada proses yang diarahkan dan dipastikan untuk memaksimalkan produktifitas karyawan, tim, dan organisasi (Mondy, 2010). Salah satu faktor perencanaan perusahaan adalah anggaran. Anggaran merupakan alat manajerial yang memastikan pencapaian target organisasional dan memberikan pedoman yang rinci untuk operasional perusahaan (Ikhsan dan Ishak, 2008). Penyusunan anggaran dalam perusahaan melibatkan para manajer baik manajer tengah maupun bawah.

Partisipasi penganggaran merupakan suatu proses dimana bawahan atau pelaksana anggaran diberikan kesempatan untuk terlibat dan mempunyai pengaruh dalam proses penyusunan anggaran (Chong dan Chong, 2002). Partisipasi penganggaran dapat meningkatkan kinerja manajerial. Hasil penelitian Rinarti dan Renyowijoyo (2007) menunjukkan bahwa partisipasi penganggaran berpengaruh secara signifikan terhadap kinerja manajerial. Hal ini diperkuat oleh hasil penelitian Sardjito dan Muthaher (2007) yang menyatakan bahwa semakin tinggi partisipasi penyusunan anggaran maka akan semakin meningkatkan kinerja.

Budaya merupakan suatu pola asumsi yang diciptakan, ditemukan, atau dikembangkan agar seseorang dapat menyesuaikan diri dalam suatu lingkungan atau organisasi (Ivancevich et al, 2006). Budaya memberikan keunikan pada suatu kelompok atau organisasi yang membedakannya dari kelompok atau organisasi lain (Ramachandran dan Krishnan, 2009). Dalam literatur akuntansi keperilakuan, Hofsted mendefinisikan budaya nasional sebagai suatu kepercayaan, nilai-nilai, dan asumsi yang dipelajari sejak masih anak-anak, yang membedakan antara satu kelompok dengan kelompok lainnya (Ikhsan dan Ishak, 2008).

Budaya organisasi mempunyai tiga fungsi utama yaitu sebagai perekat sosial yang mengikat karyawan dan membantunya untuk memahami tempatnya bekerja, suatu budaya yang kuat dapat menjadikan perusahaan bisa melakukan lebih baik dibandingkan dengan budaya yang lemah, dan 
mendorong keluarnya nilai disenting yang dapat membentuk nilai-nilai yang muncul di masa mendatang (McShane dan Von Glinow, 2010). Seorang manajer dalam membuat suatu perencanaan harus mempertimbangkan pengetahuan dan fleksibilitas dalam pebedaan budaya. Suatu kehidupan dipengaruhi oleh budaya yang berbeda sehingga manajemen yang efektif akan melakukan kerja sama. Oleh kerena itu, manajer perlu memahami suatu budaya dan berbagai karakteristik yang ada dalam budaya organisasi (Cooper, 2001 dalam Ivancevich et al, 2006).

Budaya organisasi mempunyai peran dalam meningkatkan kinerja manajerial. Hasil penelitian Rinarti dan Renyowijoyo (2007) menunjukkan bahwa budaya berpengaruh dalam memoderasi hubungan antara partisipasi penganggaran dan kinerja manajerial. Sardjito dan Muthaher (2007) menyatakan bahwa semakin tinggi tingkat kesesuaian antara partisipasi penyusunan anggaran dan budaya organisasi yang berorientasi pada orang akan semakin tinggi kinerja aparat pemerintah daerah.

Komitmen organisasi merupakan suatu keyakinan dan dukungan yang kuat terhadap nilai dan sasaran yang ingin dicapai oleh organisasi (Darlis, 2002). Komitmen organisasi mempunyai tiga komponen yaitu keyakinan yang kuat atas tujuan organisasi, kemauan seseorang untuk berusaha keras bergantung pada organisasi, dan keinginan yang terbatas untuk mempertahankan keanggotaan (Imronudin, 2004 dalam Rachmawati, 2009). Suatu komitmen organisasi akan terbangun apabila setiap individu mengembangkan tiga sikap yang saling berhubungan dengan organisasi yaitu: 1) identification, yaitu pemahaman terhadap tujuan organisasi; 2) involvement, yaitu keterlibatan dalam suatu pekerjaan dirasa menyenangkan, 3) loyality, yaitu merasa bahwa organisasi merupakan tempatnya bekerja dan tinggal (Mowday et al., dalam Ikhsan dan Ishak, 2008).

Komitmen organisasi yang kuat akan mendorong para manajer bawahan untuk berusaha keras dalam mencapai tujuan organisasi (Sumarno, 2005). Komitmen yang tinggi menjadikan individu lebih mementingkan organisasi dari pada kepentingan pribadi dan berusaha menjadikan organisasi menjadi lebih baik. Sebaliknya, komitmen organisasi yang rendah akan membuat individu berbuat untuk kepentingan pribadinya dari pada kepentingan organisasi hasil penelitian. Sumarno (2005) menunjukkan bahwa terdapat pengaruh positif dan signifikan antara komitmen organisasi terhadap hubungan antara partisipasi penganggaran dengan kinerja manajerial. Semakin tinggi tingkat komitmen organisasi akan menyebabkan peningkatan kinerja aparat pemerintah daerah dalam partisipasi penyusunan anggaran (Sardjito dan Muthaher, 2007).

\section{METODE PENELITIAN}

Populasi dalam penelitian ini adalah manajer tengah dan bawah pada perusahaan air minum dalam kemasan (AMDK) di Pasuruan. Menurut Dinas Perijinan Pasuruan ada 35 perusahaan AMDK yang terdaftar. Dalam penelitian ini hanya diambil sebanyak 20 perusahaan. Para manajer perusahaan tersebut terdiri dari manajer tengah yakni kepala bagian HRD, produksi, maintenance, pemasaran, keuangan, dan laboratorium. Manajer bawah terdiri dari kepala shif, sales dan marketing, accounting leader, serta purchasing ditetapkan sebagao objek penelitian.

Tabel 1. Hasil Perhitungan Sampel Berstrata Proporsional

\begin{tabular}{lccccc}
\hline $\begin{array}{c}\text { Tingkat } \\
\text { Manajer }\end{array}$ & Populasi & \% Dalam Populasi & $\begin{array}{c}\text { Pecahan } \\
\text { Sampling }\end{array}$ & n Sampel & \% Dalam Sampel \\
\hline Tengah & 120 & $55 \%$ & 0,30 & 36 & $55 \%$ \\
Bawah & 110 & $45 \%$ & 0,30 & 30 & $45 \%$ \\
Total & 220 & $100 \%$ & & 66 & $100 \%$ \\
\hline
\end{tabular}


Populasi dalam penelitian ini yaitu 220 manajer yang terdiri dari 120 manajer tengah dan 100 manajer bawah. Sampel ditarik menggunakan metode sampling berstrata proporsional (proporsive stratified sampling), setiap strata yaitu manajer tengah dan bawah diambil sampel sebanyak $30 \%$.

Berikut ini adalah tabel hasil perhitungan sampel berstrata proporsional.

Variabel yang digunakan dalam penelitian ini diukur dengan menggunakan instrumen-instrumen yang diadopsi dari literatur yang telah digunakan dalam penelitian dahulu. Variabel-variabel dalam penelitian ini meliputi: Pertama, Partisipasi penganggangaran (PP), yakni keterlibatan manajer menengah ke bawah dalam proses penyusunan anggaran perusahaan. Partisipasi penganggaran merupakan variabel bebas (variabel independen). Instrumen yang digunakan untuk mengukur variabel ini terdiri dari enam item pertanyaan yang dikembangkan oleh Milani (1975 dalam Supomo dan Indriantoro, 1998). Jawaban atas pertanyaan ini didesain mengunakan sekala likert dengan alternatif jawaban dari 1 sampai dengan 5. Semakin besar skor yang diperoleh menunjukkan semakin besar keterlibatan indivudu dalam partisipasi penganggaran.

Kedua, kinerja manajerial (KM) merupakan variabel terikat (variabel dependen). Kinerja manajerial dalam penelitian ini adalah kemampuan manajer baik manajer tingkat tengah atau bawah dalam mencapai kegiatan organisasi yang meliputi perencanaan, investigasi, pengkoordinasian, pengaturan, evaluasi, pengamatan, pemilihan staf, negosiasi, dan perwakilan. Pengukuran kinerja manajerial dalam penelitian ini mengunakan instrumen self-ratting yang dibangun Mahoney et al. (1963). Instrumen ini diukur dengan mengunakan skala likert 1 sampai dengan 9. Setiap responden diminta untuk menjawab delapan item pertanyaan yang menyangkut tingkat kinerja manajerial. Semakin besar sekor yang diperoleh menunjukkan semakin tinggi kinerja yang dicapai dalam pelaksanaan tugas manajerial.

Ketiga, Budaya organisasi (BO) merupakan variabel pemoderasi yaitu variabel yang memoderasi hubungan antara variabel independen (PP) dengan variabel dependen (KM). Budaya organisasi dalam penelitian ini difokuskan pada dimensi budaya (Hofstede et al, 1990) yaitu persepsi atau keyakinan yang dimiliki individu yang tercermin dalam perilaku individu tersebut dalam suatu organisasi. Budaya organisasi diukur dengan instrumen yang dikembangkan oleh Hofstede $e t$ al. (1990). Responden diminta untuk menjawab delapan pertanyaan dengan skala likert 1 sampai dengan 5.

Keempat, Komitmen organisasi (KO) juga ditempatkan sebagai variabel pemoderasi. Dalam penelitian ini, komitmen organisasi diartikan sebagai keyakinan dan dukungan yang kuat terhadap nilai dan tujuan organisasi. Variabel ini diukur dengan mengunakan pertanyaan-pertanyaan yang telah dikembangkan oleh Mowday et. al (1979) yang diadopsi dari penelitian Ritonga (2008) dengan skala likert 1 sampai 5 .

Data yang telah dikumpulkan menggunakan daftar pertanyaan tertulis dianalisis menggunakan regresi linier. Model persamaan regresi linier yang diperoleh telah diuji kemungkinan pelanggaran terhadap asumsi klasik terdiri dari multikolinieritas, heteroskedastisitas, dan normalitas. Regresi linier yang digunakan adalah linier sederhana untuk menguji hipotesis 1 dan berganda (Moderate Re-

Tabel 2. Statistik Deskriptif Variabel Penelitian

\begin{tabular}{lcccccc}
\hline \multirow{2}{*}{ Variabel } & $\mathbf{N}$ & \multicolumn{2}{c}{ Teoritis } & \multicolumn{2}{c}{ Sesungguhnya } & \multirow{2}{*}{ Std. Deviation } \\
\cline { 3 - 6 } & & Kisaran & Rata-rata & Kisaran & Rata-rata & \\
\hline PP & 68 & $1 \mathrm{~s} / \mathrm{d} 5$ & 3 & $3 \mathrm{~s} / \mathrm{d} 4$ & 3.74 & 0.372 \\
KM & 68 & $1 \mathrm{~s} / \mathrm{d} 9$ & 5 & $4 \mathrm{~s} / \mathrm{d} 8$ & 5.95 & 1.194 \\
BO & 68 & $1 \mathrm{~s} / \mathrm{d} 5$ & 3 & $3 \mathrm{~s} / \mathrm{d} 4$ & 3.5 & 0.304 \\
KO & 68 & $1 \mathrm{~s} / \mathrm{d} 5$ & 3 & $3 \mathrm{~s} / \mathrm{d} 5$ & 4.50 & 0.488 \\
\hline
\end{tabular}


gression Analysis) untuk menguji hipotesis 2 dan 3. Model yang digunakan dalam penelitian ini disajikan dalam persamaan sebagai berikut:

$$
\begin{aligned}
\mathrm{KM}= & \mathrm{a}+\mathrm{b}_{1}(\mathrm{PP})+\mathrm{b}_{2}(\mathrm{BO})+\mathrm{b}_{3}(\mathrm{KO})+ \\
& \mathrm{b}_{4}(\mathrm{PP} * \mathrm{BO})+\mathrm{b}_{5}(\mathrm{PP} * \mathrm{KO})+\mathrm{e}
\end{aligned}
$$

\section{HASIL PENELITIAN DAN PEMBAHASAN}

Kuesioner yang sebanyak 120 kuesioner dan yang diterima kembali sebanyak 76 kuesioner. Jumlah kuesioner yang bisa diproses sebanyak 68. Jadi tingkat pengembalian pada penelitian ini yaitu $56,67 \%$.
Berdasarkan hasil kuesioner yang diterima maka dapat diketahui kisaran teoritis, kisaran sesungguhnya, rata-rata, dan standar deviasi dari masing-masing variabel (tabel 2). Variabel partisipasi penganggaran (PP) mempunyai nilai terendah 3, tertinggi 4 dengan rata-rata 3,74 dan standar deviasinya 0,372 . Nilai terendah dari kinerja manajerial (KM) adalah 4 dan tertinggi 8. Adapun nilai rata-ratanya yaitu 5,95 dan standar deviasinya 1,194 . Variabel budaya organisasi (BO) mempunyai nilai terendah 3 , tertinggi 4 , nilai rata-rata 3,5 dengan standar deviasi 0,304. Komitmen organisasi (KO) mempunyai nilai terendah 3 dan tertinggi 5. Adapaun nilai rata-ratanya sebesar 4,50 dengan standar deviasi 0,488 .

Tabel 3. Hasil Uji Regresi Sederhana

\begin{tabular}{lcccc}
\hline \multicolumn{1}{c}{ Keterangan } & Adjusted $\mathbf{R}^{\mathbf{2}}$ & F & B & Sig. \\
\hline Model Summary & 0,020 & 2,335 & & 0,131 \\
Anova & & & 1,528 & 0,131 \\
Coefficients & & & & \\
\hline
\end{tabular}

Berdasarkan tabel 3 dapat diketahui bahwa besarnya nilai adjusted $R^{2}$ adalah $0,020(2 \%)$. Hal ini berartinya variabel kinerja manajerial tidak dapat dijelaskan oleh variabel partisipasi penganggaran karena nilai adjusted $R^{2}$ sangat kecil tetapi dapat dijelaskan oleh variabel lain diluar variabel penelitian ini yaitu sebesar 98\%. Uji anova menunjukkan bahwa nilai F hitung adalah sebesar 2,335 dengan tingkat signifikansi sebesar 0,131. Oleh karena nilai signifikansi lebih besar dari 0,05 maka regresi tidak dapat digunakan untuk memprediksi kinerja manajerial atau dapat dikatakan bahwa partisipasi penganggaran tidak berpengaruh terhadap kinerja manajerial.

Berdasarkan hasil uji statistik t dapat diketahui bahwa partisipasi penganggaran tidak signifikan karena nilai probabilitas signifikansinya adalah 0,131 . Nilai tersebut jauh di atas tingkat signifikansi yaitu 0,05 . Jadi dapat disimpulkan bahwa kinerja manajerial tidak dipengaruhi oleh partisipasi penganggaran.
Hipotesis satu (H1) yang menyatakan bahwa partisipasi penganggaran berpengaruh positif dan signifikan terhadap kinerja manajerial ditolak. Hal ini sejalan dengan hasil penelitian Kurnia (2004, dalam Ritonga, 2008). Tetapi hasil penelitian ini tidak sejalan dengan hasil penelitian Sumarno (2005) yang menyatakan partisipasi anggaran berpengaruh dan berhubungan negatif dengan kinerja manajerial. Hasil penelitian ini juga tidak sejalan dengan penelitian Sardjito dan Muthaher (2007) yang menyatakan partisipasi penyusunan anggaran berpengaruh secara signifikan terhadap kinerja, dan Eker (2008) yang menyatakan partisipasi penganggaran secara positif dan signifikan berpengaruh terhadap kinerja manajerial.

Keikutsertaan manajer tengah dan bawah dalam proses penyusunan anggaran tidak mempengaruhi kinerja manajerial pada perusahaan air minum dalam kemasan (AMDK) di Pasuruan. Hal ini dikarenakan pada setiap perusahaan mempunyai kebijakan dan peraturan yang berbeda antara 
perusahaan yang satu dengan yang lain. Suatu kebijakan dan peraturan dalam perusahaan ditentukan oleh manajemen puncak sehingga dalam pengambilan keputusan tergantung dari kepemimpinan atau manajemen puncak. Demikian pula dengan penentuan terhadap target anggaran. Apabila perusahaan konsisten terhadap target yang telah disepakati bersama maka kinerja manajerial akan meningkat karena jika target tidak terpenuhi akan dikenai sanksi yang tegas. Namun apabila perusahaan tidak konsisten terhadap target yang telah ditentukan maka manajer tidak akan mempunyai motivasi untuk meningkatkan kinerjanya karena tidak ada sanksi dari perusahaan.

Karakteristik anggaran menyebutkan bahwa sekali penganggaran yang telah ditetapkan telah disetujui oleh para penyusun anggaran maka anggaran hanya dapat diubah dalam kondisi tertentu (Antony dan Govindarajan, 2002). Pada pelaksanaannya, tidak semua perusahaan mempunyai kemampuan untuk fleksibel terhadap anggaran meskipun hal tersebut dapat mempengaruhi kinerja manajerial. Dalam situasi dan kondisi yang tidak memungkinkan atau berbeda maka anggaran yang ditetapkan seharusnya dapat berubah atau disesuaikan. Apabila perusahaan mempunyai kemampuan untuk menyelesaikan hal tersebut maka kinerja manajerial tidak terhambat dan akan meningkat. Tetapi apabila perusahaan tidak mempunyai kemampuan untuk menyesuaikan anggaran dengan situasi dan kondisi yang terjadi pada saat pelaksanaan maka kinerja manajerial akan terhambat yang kemudian akan menurunkan kinerja. Hal tersebut tergantung dari kebijakan atasan atau manajemen puncak. Jadi meskipun para bawahan yaitu manajer tengah dan bawah diikutsetakan dalam penyusunan anggaran tetapi atasan atau manajemen puncak tidak konsisten terhadap target dan tidak fleksibel terhadap anggaran maka partisipasi penganggaran tidak berpengaruh terhadap kinerja manajerial.

Tabel 4. Hasil Pengujian MRA

\begin{tabular}{lccccc}
\hline \multirow{2}{*}{ Keterangan } & $\begin{array}{c}\text { Adjusted R } \\
\text { Sequare }\end{array}$ & \multicolumn{2}{c}{ Anova } & \multicolumn{2}{c}{ Coefficients } \\
\cline { 3 - 6 } & 0,027 & 1,631 & 0,191 & B & Sig. \\
\hline Hipotesis 2 & & & & $-2,376$ & 0,269 \\
PP & & & & $-3,811$ & 0,130 \\
BO & & & 0,145 & 0,145 \\
Moderat & \multirow{2}{*}{0,679} & 0,054 & & \\
Hipotesis 3 & 0,070 & & & 7,538 & 0,014 \\
PP & & & & 5,577 & 0,027 \\
KO & & & $-1,526$ & 0,023 \\
Moderat & & & & & \\
\hline
\end{tabular}

Tabel 4 menunjukkan besarnya adjusted $R^{2}$ sebesar $2,7 \%$, artinya variasi kinerja manajerial tidak dapat dijelaskan oleh variasi partisipasi penganggaran, budaya organisasi, dan moderat tetapi bisa dijelaskan oleh variabel lain sebesar 97,3\% diluar variabel penelitian ini. Hasil uji anova menunjukkan nilai $F$ hitung sebesar 1,631 dengan tingkat signifikansi 0,191. Karena probabilitas signifikansi jauh lebih besar dari 0,05 maka regresi tidak dapat digunakan untuk memprediksi kinerja manajerial atau dapat dikatakan bahwa partisipasi penganggaran, budaya organisasi, dan moderat tidak berpengaruh terhadap kinerja manajerial.

Uji statistik t menunjukkan bahwa nilai koefisien variabel partisipasi penganggaran sebesar 2,376 dengan tingkat signifikansi 0,269 dan budaya organisasi sebesar -3,811 dengan tingkat signifikansi 0,130. Variabel moderat yang merupakan interaksi antara partisipasi penganggaran dengan kinerja manajerial tidak signifikan karena nilai 
signifikansinya lebih besar dari 0,05 yaitu sebesar 0,145 . Jadi dapat disimpulkan bahwa budaya organisasi bukan merupakan variabel pemoderasi sehingga hipotesis dua yang menyatakan "budaya organisasi berpengaruh positif dan signifikan dalam memoderasi hubungan anatara partisipasi penganggaran dengan kinerja manajerial" ditolak.

Hasil penelitian ini tidak mendukung hasil penelitian Sardjito dan Muthaher (2007) yang menyatakan bahwa budaya organisasi berpengaruh secara signifikan terhadap hubungan partisipasi penyusunan anggaran dengan kinerja. Hasil penelitian ini juga tidak sejalan dengan hasil penelitian Rinarti dan Renyowijoyo (2007) yang menyatakan bahwa dimensi budaya berpengaruh secara signifikan dalam memoderasi partisipasi penganggaran dengan kinerja manajerial.

Dimensi budaya pada perusahaan air minum dalam kemasan (AMDK) di Pasuruan tidak mempengaruhi partisipasi penganggaran dan kinerja manajerial. Otley (1978 dalam Sulaksono, 2005) menegaskan bahwa perbedaan hasil penelitian terjadi karena berkenaan dengan prosedur pengambilan sampel. Penarikan sampel pada penelitian ini menggunakan metode sampling berstrata proporsional pada 20 perusahaan air minum dalam kemasan di Pasuruan. Hal inilah yang membuat hasil penelitian ini berbeda dengan penelitian terdahulu karena adanya pengaruh kuat pada objek penelitian.

Budaya dalam suatu organisasi juga ditentukan oleh manajemen puncak. Budaya yang telah diciptakan dan berkembang dalam suatu organisasi tidak bisa atau tidak mudah untuk diubah. Hal tersebut tergantung pada atasan atau pemimpin perusahaan. Meskipun bawahan ikut dalam pertisipasi penganggaran namun saran yang diajukan bawahan tidak dipertimbangkan dalam membuat keputusan maka penganggaran tersebut tidak akan berpengaruh terhadap kinerja.

Nilai adjusted $R^{2}$ dalam tabel 4 sangat kecil yaitu sebesar 0,070 yang artinya variasi kinerja manajerial tidak dapat dijelaskan oleh variabel partisipasi penganggaran, komitmen organisasi, dan moderat karena pengaruhnya hanya $7 \%$. Sisanya yaitu sebsar 93\% dijelaskan oleh variabel lain yang tidak diteliti. Jika dilihat dari uji F, nilai f hitung sebesar 2,679 dengan tingkat signifikansi 0,054. Jadi model regresi tidak dapat digunakan untuk memprediksi kinerja manajerial atau dapat dikatakan bahwa partisipasi penganggaran, komitmen organisasi, dan moderat secara bersama-sama tidak berpengaruh terhadap kinerja manajerial karena tingkat probabilitas tidak signifikansi.

Uji statistik t menghasilkan nilai koefisien parameter sebesar 7,538 dengan tingkat signifikansi 0,014 pada variabel partisipasi penganggaran dan pada variabel komitmen organisasi sebesar 5,577 dengan tingkat signifikansi 0,027 . Variabel moderat yang merupakan interaksi antara partisipasi penganggaran dengan komitmen organisasi mempunyai nilai koefisien parameter sebesar -1,526 dengan nilai signifikansi sebesar 0,023 . Jadi dapat disimpulkan bahwa komitmen organisasi merupakan variabel pemoderasi.

Berdasarkan hasil uji statistik dapat disusun persamaan matematis sebagai berikut: $\mathrm{Y}=-21,613$ $+7,538 \mathrm{PP}+5,577 \mathrm{KO}-1,526 \mathrm{PP} * \mathrm{KO}$. Penjelasan dari uji statistik di atas sebagai berikut: 1) Konstanta sebesar -21,623 menyatakan bahwa jika variabel independen dianggap konstan maka rata-rata kinerja manajerial sebesar -21,623.2) Koefisien partisipasi penganggaran sebesar 7,538 menyatakan bahwa setiap peningkatan partisipasimanajer dalam penganggaran sebesar $1 \%$ akan meningkatkan kinerja manajerial sebesar 7,538. 3) Koefisien komitmen organisasi sebesar 5,577 menyatakan bahwa setiap peningkatan komitmen organisasi sebesar $1 \%$ akan meningkatkan kinerja sebesar 5,577.4) Koefisien variabel pemoderasi sebesar -1,526 menyatakan bahwa setiap interaksi antara partisipasi penganggaran dengan komitmen organisasi sebesar 1\% maka akan menurunkan kinerja manajerial sebesar 1,526.

Nilai koefisien parameter menunjukkan nilai yang negatif. Hal ini berarti komitmen organisasi berpengaruh negatif dan signifikan dalam memoderasi hubungan antara partisipasi penganggaran dan kinerja manajerial. Berdasarkan hasil tersebut maka hipotesis tiga yang menyatakan bahwa komitmen organisasi berpengaruh positif dan signifikan dalam memoderasi hubungan antara partisi- 
pasi penganggaran dengan kinerja manajerial ditolak. Hasil penelitian ini tidak sejalan dengan hasil penelitian Sumarno (2005) serta Sardjito dan Muthaher (2007) yang menyatakan bahwa komitmen organisasi berpengaruh positif dan signifikan terhadap partisipasi penyusunan anggaran dengan kinerja manajerial. Hasil penelitian ini juga tidak sejalan dengan penelitian Nouri dan Parker (1998 dalam Ritonga, 2008) yang menyatakan bahwa pengaruh komitmen organisasi terhadap hubungan antara partisipasi penganggaran dengan kinerja manajerial adalah positif dan signifikan.

Penelitian ini menunjukkan bahwa para manajer mempunyai komitmen yang tinggi terhadap organisasi. Tetapi hasil penelitian menunjukkan bahwa komitmen organisasi mempunyai pengaruh yang negatif terhadap partisipasi penganggaran dalam meningkatkan kinerja manajerial. Hasil penelitian ini bertentangan dengan pernyataan Sardjito dan Muthaher (2007) yang menyatakan bahwa komitmen organisasi yang tinggi akan meningkatkan kinerja dalam partisipasi penyusunan anggaran. Pada penelitian ini terungkap bahwa ketika komitmen para manajer terhadap organisasi tinggi maka keikutsertaan dalam penganggaran perusahaan kurang dapat meningkatkan kinerja manajerial, sehingga pelibatan para manajer dalam penganggaran tidak perlu dipaksakan. Sebaliknya pada kondisi komitmen para manajer kurang baik maka pelibatan para manajer dalam penganggaran akan sangat membantu dalam meningkatkan kinerjanya.

\section{SIMPULAN}

Berdasarkan analisis data mengenai pengaruh budaya dan komitmen organisasi terhadap hubungan antara partisipasi penganggaran dan kinerja manajerial maka dapat disimpulkan bahwa peran manajer dalam partisipasi penganggaran perusahaan tidak dapat meningkatkan kinerja manajerial. Semakin kuat budaya organisasi maka tidak atau kurang memerlukan pelibatan para manajer dalam penganggaran perusahaan. Sebaliknya, semakin lemah budaya organisasi suatu perusahaan maka semakin diperlukan pelibatan para manajer dalam penganggaran perusahaan. Semakin tinggikomitmen organisasi maka tidak memerlukan pelibatan para manajer dalam penganggaran perusahaan. Sebaliknya, semakin rendah komitmen organisasi maka semakin memerlukan pelibatan para manajer dalam penganggaran perusahaan.

\section{DAFTAR PUSTAKA}

Ardianto, Yogi (2008). Analisis Pengaruh Partisipasi Penyusunan Anggaran Terhadap Kinerja Manajerial Dengan Kepuasan Kerja, job Relevant Information dan Motivasi Kerja Sebagai Variabel Moderating. Tesis Program Studi Magister Sains Akuntansi. Universitas Diponegoro. Semarang Arikunto, Suharsimi (2006). Prosedur Penelitian (Suatu Pendekatan Praktik). Edisi Revisi VI. Rineka Cipta. Jakarta

Chong, Vincent K and Chong, Kar Ming (2002). Budget Goal Commitment and Informational Effect of Budget Participation on Performance: A Structural Aquation Modelling Approach, Behvioral Research in Accounting Journal.

Darlis, Edfan, Analisa Pengaruh Komitmen Organisasional dan Ketidak Pastian Lingkungan terhadap Hubungan antara Partisipasi Anggaran dengan Senjangan Anggaran, Jurnal Riset Akuntansi Indonesia, Vol. 5 No.1 Januari 2002, Hal. 85 - 101.

Eker, Melek (2008). "The Effect of The Relationship Between Budget Participation and Job Relevant Information on Managerial Performance." Ege Academic Review, 8, 183198.

Ghozali, Imam (2005). Aplikasi Analisis Multivariate dengan Program SPSS. Semarang: Penerbit Universitas Diponegoro.

Ikhsan, Arfan \& Ishak, Muhammad (2008). Akuntansi Keperilakuan. Cetakan ketiga. Jakarta: Penerbit Salemba empat.

Ivancevich, John M.; Konopaske, Robert; dan Mattenson, Michael T. (2006). Perilaku dan Manajemen Organisasi. Jilid 1. Edisi Ketujuh. Penerbit Erlangga. 
Leach-Lopez, Maria A., Stammerjohan, William W. \& Lee, Kyoo Sang (2007). Budget Participation and Job Performance of South Korea Managers Mediated by Job Satisfaction and Job Relevant Information. Global Conference on Business\& Economics.

McShane, Staven L. and Von Glinow, Mary Ann (2010). Organizational Behavior, Emerging Knowledge and Practice for The Real World. Fifth Edition. International Edition. McGraw-Hill.

Mondy, R. Wayne, (2010). Human Resource Management. Eleventh edition. Pearson.

Rachmawati, Shinta Rina (2009). Pengaruh Komitmen Organisasi, Motivasi Kerja, dan Gaya Kepemimpinan Terhadap Kinerja Karyawan Bidang Keuangan pada PEMDA Kabupaten Sukoharjo. Skirpsi. Universitas Muhammadiyah Surakarta

Ramachandran, Sudha \& Krishnan, Venkat R. (2009). "Effect of Transformational Leadership on Followers' Affective and Normative Commitment: Culture as Moderator." Great Lakes Institute of Management. Vol. 3. No. 1, 23-38.

Rinarti, Deasy \& Renyowijoyo, Muindro (2007). "Pengaruh Ketidakpastian Lingkungan dan Budaya organisasi Terhadap Partisipasi Penganggaran dan Kinerja Manajerial." Jurnal Bisnis dan Akuntansi. Vol. 9, No. 2, 124-135.

Ritonga, Panangaran (2008). Pengaruh Budaya Paternalistik dan Komitmen Organisasi terhadap Hubungan Antara Partisipasi
Anggaran dan Kinerja Manajerial pada

PDAM Tirtanadi Propinsi Sumatera Utara. Tesis Pascasarjana Universitas Sumatera Utara, Medan.

Rudhianto, Hermawan (2010). Pengaruh Komitmen Organisasi dan Gaya Kepemimpinan terhadap Hubungan Antara Partisipasi Anggaran dan Kinerja. Tesis Magister Akuntansi Universitas Sebelas Maret, Surakarta.

Sardjito, Bambang \& Muthaher, Osmad (2007). "Pengaruh Partisipasi Penyusunan Anggaran Terhadap Kinerja Aparat Pemerintah Daerah: Budaya Organisasi dan Komitmen Organisasi sebagai Variabel Moderating." Simposium Nasional Akuntansi X. Unhas Makassar.

Sulaksono, Tri (2005). Budaya Organisasi Dan Ketidakpastian Lingkungan Sebagai Variabel Moderating Dalam Hubungan Antara Gaya Evaluasi Atasan Terhadap Tekanan Kerja dan Kepuasan Kerja Bawahan. Tesis Magister Akuntansi Universitas Diponegoro. Semarang.

Sumarno, J. (2005). "Pengaruh Komitmen Organisasi dan Gaya Kepemimpinan Terhadap Hubungan antara Partisipasi Anggaran dan Kinerja Manajerial." Simposium Nasional Akuntansi VIII Solo. Supomo, Bambang \& Indriantoro, Nur (1998). "Pengaruh Struktur dan Kultur Organisasional Terhadap Keefektifan Anggaran Partisipatif dalam Peningkatan Kinerja Manajerial." KELOLA. No. 8. 
